\title{
Biotransformation of acetophenone and its halogen derivatives by Yarrowia lipolytica strains
}

\author{
Tomasz Janeczko • Wojciech Bąkowski • Ewa Walczak • \\ Malgorzata Robak • Jadwiga Dmochowska-Gladysz • \\ Edyta Kostrzewa-Suslow
}

Received: 9 April 2014 / Accepted: 4 August 2014 / Published online: 22 August 2014

(C) The Author(s) 2014. This article is published with open access at Springerlink.com

\begin{abstract}
The ability of 16 strains of Yarrowia lipolytica to biotransform acetophenone and its derivatives has been studied. Thirteen of these strains were derived from a wild-type strain Y. lipolytica A-101; six had the invertase gene (SUC2) from Saccharomyces cerevisiae integrated into their genome, as well as the damaged or undamaged gene encoding orotidine-5'-phosphate decarboxylase (URA3), three had integrated the damaged URA3 gene into their genome and three were UV acetate-negative mutants, not able to growth on acetate as the sole carbon source. The other tested strains included two wild strains, A-101 and PMR-1, and an adenine auxotroph ATCC 32-338A. All strains were capable of reducing acetophenone to the $R$-alcohol in high enantiomeric excess (80-89\%). In all of the cultures tested, reversibility of the reduction was observed, which led to an increase in the enantiomeric excess. nantioselective reduction of the acetophenone halogen derivatives revealed that the nature and location of the halogen atom had a significant influence on the enantioselectivity of the reduction. In the culture of ATCC 32-338A, after a 3-day biotransformation of 2,4'-
\end{abstract}

T. Janeczko $(\bowtie) \cdot$ W. Bąkowski · J. Dmochowska-Gładysz •

E. Kostrzewa-Susłow

Department of Chemistry, Wrocław University of Environmental and

Life Sciences, Norwida 25, 50-375 Wrocław, Poland

e-mail: janeczko13@interia.pl

E. Walczak $\cdot$ M. Robak

Department of Biotechnology and Food Microbiology, Wroclaw University of Environmental and Life Sciences, Norwida 25, 50-375 Wrocław, Poland

\section{E. Walczak}

Department of Medicine, The Witelon University of Applied

Sciences, Sejmowa 5A, 59-220 Legnica, Poland

J. Dmochowska-Gładysz

Department of Cosmetology, Wrocław College of Physiotherapy,

Kościuszki 4, 50-038 Wrocław, Poland dibromoacetophenone the enantiopure $R$-alcohol was obtained at a rate of $100 \%$ of substrate conversion. In conclusion, using these invertase-containing strains or uracyl auxotrophs provided no additional benefit in terms of biotransformation capacity over the parental strain.

Keywords Yarrowia lipolytica $\cdot$ SUC2 - URA3 . Enantiospecific reduction $\cdot$ Halogen derivatives of acetophenone

\section{Introduction}

Yarrowia lipolytica is a dimorphic yeast that forms creamcolored, wrinkled, rough or smooth surfaced colonies (Domínguez et al. 2000; Perez-Campo and Domínguez 2001; Ding et al. 2004). Strains of this species have been isolated from margarine, cereal plants, high-protein meat products, vegetables, frozen food, wines, tar and petroleumcontaminated soil (Wojtatowicz et al. 1993; Alkasrawi et al. 1999; Deak et al. 2000; Thevenieau et al. 2009; Robak et al. 2011). This yeast can grow on many nutrients, including glucose, fructose, organic acids, alcohols, acetate or hydrophobic substances, such as fatty acids and alkanes (Wojtatowicz et al. 1991; Ravindra 2000), but growth is thiamine-dependent. It has outstanding physiological and biochemical properties, mainly due to the ability to use unconventional carbon sources and the secretion of extracellular hydrolases. Y. lipolytica is capable of growth on waste substrates, such as hydrolyzed molasses, spent sulfite liquor and raw glycerol, and therefore can qualify as a producer of cheap single cell biomass (SCB). This biomass is a valuable source of vitamins, exogenous amino acids and unsaturated fatty acids for animal feed (fodder yeasts) (Juszczyk et al. 2005). Moreover, in terms of human health, yeast proteins contain more of the exogenous amino acids (lysine, leucine, 
methionine) than algal and plant proteins (Ravindra 2000). Because of its proteolytic and lipolytic activities, this yeast is used in cheese production, particularly in the ripening process (Wojtatowicz et al. 2001; Lanciotti et al. 2005; Czajgucka et al. 2006).

Yarrowia lipolytica is capable of synthesizing lactones through the transformation of fatty acids (Pagot et al. 1998). One of the products is gamma-decalactone of peach aroma, produced from castor oil (Wojtatowicz et al. 1991; Fantin et al. 2001). Other valuable products are organic acids, such as citric, isocitric, oxoglutaric and pyruvic acids (Morgunov et al. 2004, 2013; Finogenova et al. 2005; Thevenieau et al. 2009) and erythritol (Tomaszewska et al. 2014; Mirończuk et al. 2014). Therefore, it is a species of great biotechnological importance in biosynthesis, biodegradation and biotransformation processes (Bankar et al. 2009; Coelho et al. 2010; Robak et al. 2011; Żogała et al. 2012; Rywinska et al. 2013).

Nowadays $Y$. lipolytica is categorized as a hemiascomycetous yeast, however phylogenetically it is distantly related to Saccharomyces cerevisiae (Sherman et al. 2004; Richard et al. 2005; Acker et al. 2008; Mekour et al. 2010; Naumova et al. 2010). The genome of Y. lipolyica was sequenced 10 years ago (Casaregola et al. 2000; Sherman et al. 2004) and unusual characteristics were found. The most important of these are its size (20.5 Mbp, twice the size of the $S$. cerevisiae genome), considerably high contents of $\mathrm{G}+\mathrm{C}$ (49\%), the presence of 1,119 introns, chromosomal features of atypical structure (centromers and replication origins), a large number of tRNA genes (510), dispersed 5S rRNA genes (109 copies) and a novel organization of RNA genes (Acker et al. 2008; Mekour et al. 2010). The focus of much current research is the the study of new aspects of gene expression regulation (Neuveglise et al. 2005; Mekour et al. 2010; Blazek et al. 2011), which has resulted in the description of new phylogenetically related species (Knutsen et al. 2007; Michely et al. 2013).

Yarrowia lipolytica metabolizes only a few monosaccharides, namely, glucose, fructose, mannose and ribose. It cannot utilize polysaccharides and disaccharides, such as sucrose or lactose (Madzak et al. 2004; Morgunov et al. 2004; Rywinska et al. 2013). Since the 1980s there have been a persistent effort to effect the genetic improvement and development of $Y$. lipolytica strains, with a focus the efficient production of heterologous proteins or organic acids (Gasmi et al. 2001, 2011; Nicaud 2012).

One relatively easy approach to select potential new producers can be selection based on the ability to metabolize a non-typical (for the species under study) source of carbon, i.e. sucrose. Sucrose undergoes hydrolysis to glucose and fructose in the reaction catalyzed by an invertase, the enzyme encoded by the SUC2 gene in S. cerevisiae. Strains of Y. lipolytica containing invertase $\left(\mathrm{Suc}^{+}\right)$have been obtained by Nicaud et al. (1989), Förster et al. (2007) and Walczak and Robak
(2009). Due to their capacity to grow on sucrose, recombinant strains of $Y$. lipolytica can utilize sucrose-containing substrates, such as non-hydrolyzed molasses and table sugar (Nicaud et al. 1989; Li et al. 2012). Y. lipolytica transformants with the $\mathrm{Suc}^{+}$phenotype differ by various metabolic properties from the parental strain (Lazar et al. 2011, 2013; Michely et al. 2013) and therefore can be regarded as having a novel biotransformation ability.

Growing interest in the synthesis of enantiomerically pure compounds has promoted a great development in biocatalysis. Biotransformation is a convenient method for preparing chiral compounds. Chiral alcohols have been prepared through the reduction of aromatic ketones using yeast, fungi, bacteria, plants and isolated enzymes as biocatalysts. Enantiopure alcohols are useful chiral building blocks in the asymmetric synthesis of bioactive compounds of complex structures (Linder et al. 1989; Yadav et al. 2001; White et al. 2006; Janeczko et al. 2013). For this reason, studies on effective ways of obtaining these compounds on a preparative scale have been undertaken. The asymmetric reduction of ketones with the help of biocatalysts is a method that fulfills green chemistry requirements (Nakamura et al. 2003). In recent years several reports on the employment of isolated dehydrogenases for enantiospecific reduction have appeared (Zhu et al. 2009; Hoff and Sundby 2013; Xu et al. 2013; Rodríguez et al. 2014). The alcohol dehydrogenase from the hyperthermophilic archaeon Pyrococcus furiosus (PFADH) effectively catalyzes the reduction of various substituted $\alpha$ chloroacetophenones to form the $(R)$-enantiomers of the corresponding chlorohydrins with an excellent enantiomeric purity (Zhu et al. 2009; ). However, the employment of intact microorganism cells of both growing and resting-state cultures eliminates problems with the regeneration of co-factors cooperating with enzymes. The associated low costs and simplicity of the microbial reduction of the carbonyl group make this experimental procedure an interesting alternative to methods which use synthetic catalysts (Coelho et al. 2010).

As substrates for the tests reported here we have chosen $\alpha$ halogen derivatives of acetophenone because products of their reduction are used as chiral synthons in the pharmaceutical industry. The examples used here are the syntheses of $(R)-(-)$ formoterol, $(R)-(-)$-isoproterenol, $(R)-(-)$-salmeterol, $(R)-(-)$ denopamine, D-sotalol and $(R)-(-)$-clorprenalin (Corey and Helel 1998; Goswami et al. 2001), which are important beta2-adrenergic receptor agonist drugs.

The aim of this study was to test 16 strains of Y. lipolytica for their ability to transform acetophenone and its halogen derivatives. Nine strains are new, derived from a wild-type Y. lipolytica strain A-101, by genetic transformation (Walczak and Robak 2009). With the help of gene engineering tool,s some of transformants were obtained by homologous integration into the genome of the SUC2 gene (clones Suc ${ }^{+}$ura ${ }^{-}$) and others by non-homologous gene integration (clones $\mathrm{Suc}^{+} \mathrm{Ura}^{+}$ 
and suc ${ }^{-}$ura $^{-}$). One of the clones obtained had two copies of the invertase gene (Lazar et al. 2011). All of these strains could potentially manifest new biotransformation properties.

\section{Materials and methods}

\section{Substrates and strains}

The substrates used in this study are acetophenone (1), 2,4'dichloroacetophenone (3), 2,2',4'-trichloroacetophenone (4), 2-chloro-4'-fluoroacetophenone (5), 2-bromo-4'chloroacetophenone (6) and 2,4'-dibromoacetophenone (7); all were purchased from Sigma-Aldrich (St. Louis, MO). All racemic alcohols $(\mathbf{2}, \mathbf{8}-\mathbf{- 1 2})$ were prepared by reducing the corresponding ketone with sodium borohydride in methanol.

The strains of Y. lipolytica were obtained from the Department of Biotechnology and Food Microbiology, Wrocław University of Environmental and Life Sciences and included (1) A-101 (wild-type parental strain), (2) A-101-1.31 (acetatenegative UV mutant of A-101), (3) A-101-1.31-K1 (smooth segregant of acetate-negative UV mutant of A-101-1.31), (4) A-101-1.22 (acetate-negative UV mutant of A-101), (5) PMR-1 (isolated from soil contaminated by fuel) and (6) ATCC 32-338A (adenine auxotroph purchased from the American Type Culture Collection). Also tested were transformants of A-101: (7) A18 (Suc ${ }^{+} \mathrm{ura}^{-}$), (8) B54-6

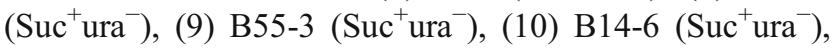
(11) B57-4 (Suc ${ }^{+}$ura $^{-}$), (12) B1-1 ( suc $^{-}$ura $^{-}$), (13) A50 (suc ura ), (14) B9-2 (suc ura ), (15) Klon1 ( Suc $^{+} \mathrm{Ura}^{-}$) and (16) B56-5 ( $\left.\mathrm{Suc}^{+} \mathrm{Ura}^{+}\right)$.

Strains numbers 7-16 underwent genetic transformation by a yeast cassette carrying the $S U C 2$ invertase gene from S. cerevisaie, flanked by two ura3 sequence fragments, homologous to the native URA3 gene, encoding orotidine-5'phosphate decarboxylase from Y. lipolytica. Using the transformation procedure described by Walczak and Robak (2009), we obtained three groups of recombinants. The first group (\#8-11) consisted of four strains recombined at the desired site, characterized by the $\mathrm{Suc}^{+}$ura ${ }^{-}$phenotype. The second group (\#12-14) contained suc ${ }^{-}$ura $^{-}$strains, in which the cassette was not fully exchanged and, therefore, these strains did not gain the ability to grow on sucrose and become uracil auxotrophs. The third group $(\# 15,16)$ were strains in which the DNA hybridization took place at a location other than the target location, giving the strains the $\mathrm{Suc}^{+} \mathrm{Ura}^{+}$phenotype. Y. lipolytica transformant B56-5 has two invertase encoding genes (Lazar et al. 2011).

Culture media

The YPG growth medium was prepared with yeast extract $(10 \mathrm{~g} / \mathrm{l})$, peptone $(20 \mathrm{~g} / \mathrm{l})$ and glucose $(20 \mathrm{~g} / \mathrm{l})$ and was sterilized in an autoclave at $121{ }^{\circ} \mathrm{C}$ for $20 \mathrm{~min}$. Thiamine $(0.3 \mathrm{mg} / \mathrm{l})$ and uracil $(20 \mathrm{mg} / \mathrm{l})$ were added after sterilization.

The minimal growth medium MMT containing sucrose was prepared by mixing the following ingredients in $100 \mathrm{ml}$ of water: $\left(\mathrm{NH}_{4}\right) \mathrm{H}_{2} \mathrm{PO}_{4}(5 \mathrm{~g} / \mathrm{l}), \mathrm{KH}_{2} \mathrm{PO}_{4}(2.5 \mathrm{~g} / \mathrm{l}), \mathrm{MgSO}_{4}$. $7 \mathrm{H}_{2} \mathrm{O}(1 \mathrm{~g} / \mathrm{l})$ and $1 \mathrm{ml} / 1$ of mineral salts $\left[\mathrm{Ca}\left(\mathrm{NO}_{3}\right)_{2} \cdot 4 \mathrm{H}_{2} \mathrm{O}\right.$ $(2 \mathrm{~g}), \mathrm{Na}_{2} \mathrm{MoO}_{4}(20 \mathrm{mg}), \mathrm{FeCl}_{3} \cdot 6 \mathrm{H}_{2} \mathrm{O}(200 \mathrm{mg}), \mathrm{CuSO}_{4}$. $5 \mathrm{H}_{2} \mathrm{O}(10 \mathrm{mg}), \mathrm{H}_{3} \mathrm{BO}_{3}(50 \mathrm{mg}), \mathrm{CoCl}_{2}(10 \mathrm{mg}), \mathrm{MnSO}_{4}$. $4 \mathrm{H}_{2} \mathrm{O}(40 \mathrm{mg}), \mathrm{KI}(10 \mathrm{mg}), \mathrm{ZnSO}_{4} \cdot 7 \mathrm{H}_{2} \mathrm{O}(40 \mathrm{mg})$. After sterilization in an autoclave, sucrose $(10 \mathrm{~g} / \mathrm{l})$, thiamine $(0.3 \mathrm{mg} / \mathrm{l})$ and uracil $(20 \mathrm{mg} / \mathrm{l})$ were added.

\section{Growth conditions}

For the analytical tests the biological material stored on agar slants was transferred into $250 \mathrm{ml}$ Erlenmeyer flasks containing $50 \mathrm{ml}$ of YPG or MMT medium with the appropriate additives. Then flasks with the cultures were then placed on a shaker $(150 \mathrm{rpm})$ for $24 \mathrm{~h}$ at $25^{\circ} \mathrm{C}$.

For the preparative-scale biotransformations, yeasts cultures were cultivated in 2,000-ml Erlenmeyer flasks containing $500 \mathrm{ml}$ of YPG medium with appropriate additives on a shaker $(150 \mathrm{rpm})$ for $24 \mathrm{~h}$ at $25^{\circ} \mathrm{C}$.

\section{Screening procedure}

For the analytical tests the cultures were centrifuged under aseptic conditions $\left(21,460 \mathrm{~g}\right.$ for $10 \mathrm{~min}$ at $25^{\circ} \mathrm{C}$ ), and the biomass [number of cells $\approx 5 \times 10^{8}(\mathrm{cell} / \mathrm{ml})$ ] was transferred into 250 -ml Erlenmeyer flasks containing $50 \mathrm{ml}$ of previously sterilized phosphate buffer (1/15 M, pH 6.47). After transferring the biomass to the buffer, $10 \mathrm{mg}$ of a substrate dissolved in $1 \mathrm{ml}$ of acetone was added. After 1, 3, 6 or 9 days of incubation at room temperature and continuous shaking $\left(150 \mathrm{rpm}\right.$ at $\left.25^{\circ} \mathrm{C}\right), 10-\mathrm{ml}$ samples of the transformation mixture were removed. All procedure were carried out under aseptic conditions in microbiological safety cabinets (TopSafe 1.5, BIOAIR) or laminar flow clean benches (BIO 48, FASTER). The samples were extracted with $10 \mathrm{ml}$ of $\mathrm{CHCl}_{3}$, dried over $\mathrm{MgSO}_{4}$, concentrated in vacuo and analyzed by GC. All the experiments were repeated three times.

Preparative biotransformation

For the preparative-scale biotransformation the substrates (200 $\mathrm{mg}$ of each of compounds dissolved in $2 \mathrm{ml}$ of acetone) were added to the cultures cultivated in 2,000-ml flasks (each containing $500 \mathrm{ml}$ of the culture). The biotransformation mixtures were incubated under the same conditions $\left(150 \mathrm{rpm}, 25^{\circ} \mathrm{C}\right)$ for $48 \mathrm{~h}$. The mixtures were then extracted three times with $300 \mathrm{ml}$ of $\mathrm{CHCl}_{3}$, dried over $\mathrm{MgSO}_{4}$ and concentrated in vacuo. Transformation products were separated by column chromatography using silica gel (Kieselgel 60, 
230-400 mesh; Merck \& Co., Whitehouse Station, NJ) and a hexane/acetone mixture $(3: 1, \mathrm{v} / \mathrm{v})$ as the eluent.

Analytical methods

The course of both the biotransformation and oxidation processes were followed using thin layer chromatography (TLC), and the composition of each product mixture was determined by capillary gas chromatography (CGC). Analytical TLC was carried out on silica gel G (Merck) with different developing systems. Compounds were detected by spraying the plates with $1 \% \mathrm{Ce}\left(\mathrm{SO}_{4}\right)_{2}$ and $2 \% \mathrm{H}_{3}\left[\mathrm{P}\left(\mathrm{Mo}_{3} \mathrm{O}_{10}\right)_{4}\right]$ in $10 \%$ $\mathrm{H}_{2} \mathrm{SO}_{4}$. GC analysis was performed using a HewlettPackard 5890A (Series II; Hewlett-Packard Co., Palo Alto, CA) GC instrument fitted with a flame ionization detector (FID). A chiral capillary column [Chrompack WCOT Fused Silica (CP Chirasil-DEX CB)], $25 \mathrm{~m} \times 0.25 \mathrm{~mm} \times 0.25 \mu \mathrm{m}$, (Varian Inc., Lake Forest, CA, ) was used to determine the composition of the unreacted substrates and product mixtures. Nuclear magnetic resonance (NMR) spectra were recorded with a DRX 500-MHz Bruker spectrometer (Bruker Corp., Billerica, $\mathrm{MA}$ ) and measured in $\mathrm{CDCl}_{3}$. Optical rotations were measured with an Autopol IV automatic polarimeter (Rudolph Research Analytical, Hackettstown, NJ).

The GC conditions were an injector temperature of $200^{\circ} \mathrm{C}$ and a detector temperature of $250^{\circ} \mathrm{C}$. The temperature programs for enantiomeric resolution of particular compounds are as follows:

- 1-phenylethan-1-ol (2): $90{ }^{\circ} \mathrm{C} / 1 \mathrm{~min}, 3{ }^{\circ} \mathrm{C} \min ^{-1}$ to $105^{\circ} \mathrm{C}, 30{ }^{\circ} \mathrm{C} \mathrm{min}^{-1}$ to $200{ }^{\circ} \mathrm{C} / 5 \mathrm{~min}, R_{\mathrm{t}}(R) 4.97 \mathrm{~min}$, $R_{\mathrm{t}}(\mathrm{S}) 5.42 \mathrm{~min}$.

- 2,4'-dichloro-1-phenylethan-1-ol (8): $142{ }^{\circ} \mathrm{C} / 1 \mathrm{~min}$, $2{ }^{\circ} \mathrm{C} \mathrm{min}{ }^{-1}$ to $165{ }^{\circ} \mathrm{C}, 30{ }^{\circ} \mathrm{C} \min ^{-1}$ to $200{ }^{\circ} \mathrm{C} / 5 \min , R_{\mathrm{t}}$ (S) $10.05 \mathrm{~min}, R_{\mathrm{t}}(R) 10.69 \mathrm{~min}$.

- 2,2',4'-trichloro-1-phenylethan-1-ol (9): $165{ }^{\circ} \mathrm{C} / 1 \mathrm{~min}$, $2{ }^{\circ} \mathrm{C} \mathrm{min}{ }^{-1}$ to $178{ }^{\circ} \mathrm{C}, 20{ }^{\circ} \mathrm{C} \min ^{-1}$ to $200{ }^{\circ} \mathrm{C} / 5 \min , R_{\mathrm{t}}$ (R) $6.84 \mathrm{~min}, R_{\mathrm{t}}(S) 7.42$ min.

- 2-chloro-4'-fluoro-1-phenylethan-1-ol (10): $140{ }^{\circ} \mathrm{C} / 1 \mathrm{~min}$, $2{ }^{\circ} \mathrm{C} \mathrm{min}^{-1}$ to $150{ }^{\circ} \mathrm{C}, 20^{\circ} \mathrm{C} \mathrm{min}^{-1}$ to $200^{\circ} \mathrm{C} / 5 \mathrm{~min}, R_{\mathrm{t}}(R)$ $4.24 \mathrm{~min}, R_{\mathrm{t}}(S) 4.64 \mathrm{~min}$.

- 2-bromo-4'-chloro-1-phenylethan-1-ol (11): $160{ }^{\circ} \mathrm{C} /$ $1 \mathrm{~min}, 2{ }^{\circ} \mathrm{C} \min ^{-1}$ to $178{ }^{\circ} \mathrm{C}, 20{ }^{\circ} \mathrm{C} \min ^{-1}$ to $200{ }^{\circ} \mathrm{C} /$ 5 min, $R_{\mathrm{t}}(R) 9.49 \min , R_{\mathrm{t}}(S) 9.93 \min$.

- 2,4'-dibromo-1-phenylethan-1-ol (12): $150{ }^{\circ} \mathrm{C} / 1 \mathrm{~min}$, $2{ }^{\circ} \mathrm{C} \mathrm{min}{ }^{-1}$ to $183{ }^{\circ} \mathrm{C}, 20{ }^{\circ} \mathrm{C} \mathrm{min}{ }^{-1}$ to $200{ }^{\circ} \mathrm{C} / 5 \min , R_{\mathrm{t}}$ (R) 14.20 min, $R_{\mathrm{t}}(S) 14.73$ min.

\section{Identification of products}

The obtained products proved to be secondary alcohols. The locations and orientations of the newly formed hydroxyl groups were determined on the basis of chemical shifts and shapes of the $\mathrm{CHOH}$ signals in the ${ }^{1} \mathrm{H}$ NMR spectra:

- (R)-1-phenylethan-1-ol (2) $[\alpha]_{D}^{20}=+38.6^{\circ}\left(c=3.0 \mathrm{CHCl}_{3}\right)$ (79\% ee); \{Omori et al. (2007) $[\alpha]_{D}^{20}=+51^{\circ}, 99 \%$ enantiomeric excess (ee) $\} ;{ }^{1} \mathrm{H}$ NMR $\left(\mathrm{CDCl}_{3}\right) \delta 1.47(\mathrm{~d}$, $\left.3 \mathrm{H}, J=6.5 \mathrm{~Hz}, \mathrm{CH}_{3}\right), 2.79$ (s, $\left.1 \mathrm{H}, \mathrm{OH}\right), 4.79$ (q, $1 \mathrm{H}, J=$ $6.5 \mathrm{~Hz}, \mathrm{CH}-\mathrm{OH}$ ), and 7.14-7.21 (m, 5H, $H-\mathrm{Ar}$ ).

- (S)-2,4'-dichloro-1-phenylethan-1-ol (8) $[\alpha]_{D}^{20}=+27.2^{\circ}$ $\left(c=3.45 \mathrm{CHCl}_{3}\right)\left(86 \%\right.$ ee); $\left\{\right.$ Wei et al. (1998), $[\alpha]_{D}^{20}=+$ $\left.44.2^{\circ}, 96.6 \% \mathrm{ee}\right\} ;{ }^{1} \mathrm{H} \mathrm{NMR}\left(\mathrm{CDCl}_{3}\right) \delta 2.67(\mathrm{~s}, 1 \mathrm{H},-\mathrm{OH})$, $3.60\left(\mathrm{dd}, 1 \mathrm{H}, J=11.3,8.6 \mathrm{~Hz}\right.$, one of $\left.\mathrm{CH}_{2}\right), 3.71(\mathrm{dd}, 1 \mathrm{H}$, $J=11.3,3.5 \mathrm{~Hz}$, one of $\left.\mathrm{CH}_{2}\right), 4.88(\mathrm{dd}, 1 \mathrm{H}, J=8.6,3.4 \mathrm{~Hz}$, $\mathrm{CH}-\mathrm{OH}$ ), and 7.26-7.39 (m, 4H, $H-\mathrm{Ar})$.

- (R)-2,2',4'-trichloro-1-phenylethan-1-ol (9) $[\alpha]_{D}^{20}=$ $-26.1^{\circ}\left(c=1.0 \mathrm{CHCl}_{3}\right)(68 \%$ ee); (Huang and Ying (2007), $[\alpha]_{D}^{20}=-59.1^{\circ}, 90-92 \%$ ee $\} ;{ }^{1} \mathrm{H}$ NMR $\left(\mathrm{CDCl}_{3}\right)$ $\delta 2.82(\mathrm{~s}, 1 \mathrm{H}, \mathrm{OH}), 3.52 \mathrm{dd}, 1 \mathrm{H}, J=11.3,8.5 \mathrm{~Hz}$, one of $\mathrm{CH}_{2}$ ), 3.87 (dd, $1 \mathrm{H}, J=11.3,2.8 \mathrm{~Hz}$, one of $\left.\mathrm{CH}_{2}\right), 5.26$ (dd, $1 \mathrm{H}, J=8.5,2.8 \mathrm{CH}-\mathrm{OH}), 7.31(\mathrm{dd}, 1 \mathrm{H}, J=8.3$, $2.2 \mathrm{~Hz}, H 5^{\prime}-\mathrm{Ar}$ ), 7.38 (d, H1, J=2.2 Hz, H6'-Ar), and 7.58 (d, $\left.1 \mathrm{H}, J=8.3 \mathrm{~Hz}, H 3^{\prime}-\mathrm{Ar}\right)$.

- (S)-2-chloro-4'-fluoro-1-phenylethan-1-ol (10) $[\alpha]_{D}^{20}=+$ $34.7^{\circ}\left(c=4.75 \mathrm{CHCl}_{3}\right)(80 \%$ ee $)$; $\{$ Nieduzak and Margolin (1991), $[\alpha]_{D}^{20}=+51^{\circ}, 97 \%$ ee $\} ;{ }^{1} \mathrm{H}$ NMR $\left(\mathrm{CDCl}_{3}\right) \delta 2.73(\mathrm{~s}, 1 \mathrm{H}, \mathrm{OH}), 3.61(\mathrm{dd}, 1 \mathrm{H}, J=11.3$, $8.7 \mathrm{~Hz}$, one of $\left.\mathrm{CH}_{2}\right), 3.71(\mathrm{dd}, 1 \mathrm{H}, J=11.3,3.5 \mathrm{~Hz}$, one of $\left.\mathrm{CH}_{2}\right), 4.88(\mathrm{dd}, 1 \mathrm{H}, J=8.7,3.5 \mathrm{~Hz}, \mathrm{CH}-\mathrm{OH}), 7.04-7.09$ (m, 2H, H3', ' $-\mathrm{Ar}$ ), and 7.32-7.38 (m, 2H, H2', 6'-Ar).

- (S)-2-bromo-4'-chloro-1-phenylethan-1-ol (11) $[\alpha]_{D}^{20}=+$ $14.3^{\circ}\left(c=1.2 \mathrm{CHCl}_{3}\right)(42 \%$ ee $)$; Basavaiah et al. (2004), $\left.[\alpha]_{D}^{20}=+39.0^{\circ}, 89 \% \mathrm{ee}\right\} ;{ }^{1} \mathrm{H} \mathrm{NMR}\left(\mathrm{CDCl}_{3}\right) \delta 2.69(\mathrm{~s}, 1 \mathrm{H}$, $\mathrm{OH}), 3.50\left(\mathrm{dd}, 1 \mathrm{H}, J=10.5,8.8 \mathrm{~Hz}\right.$, one of $\left.\mathrm{CH}_{2}\right), 3.61(\mathrm{dd}$, $1 \mathrm{H}, J=10.5,3.4 \mathrm{~Hz}$, one of $\left.\mathrm{CH}_{2}\right), 4.91(\mathrm{dd}, 1 \mathrm{H}, J=8.8$, $3.4 \mathrm{~Hz}, \mathrm{CH}-\mathrm{OH}$ ), and 7.20-7.28 (m, 4H, Hz, $H-\mathrm{Ar})$.

- (S)-2,4'-dibromo-1-phenylethan-1-ol (12) $[\alpha]_{D}^{20}=-36.1^{\circ}$ $\left(c=1.8 \mathrm{CHCl}_{3}\right)(100 \%$ ee $) ;$ Basavaiah et al. 2004), $[\alpha]_{D}^{20}$ $=+33.8^{\circ}, 96 \%$ ee $\} ;{ }^{1} \mathrm{H} \mathrm{NMR}\left(\mathrm{CDCl}_{3}\right) \delta 2.75(\mathrm{~s}, 1 \mathrm{H}, \mathrm{OH})$, $3.49\left(\mathrm{dd}, 1 \mathrm{H}, J=10.5,8.7 \mathrm{~Hz}\right.$, one of $\left.\mathrm{CH}_{2}\right), 3.60(\mathrm{dd}, 1 \mathrm{H}$, $J=10.5,3.4 \mathrm{~Hz}$, one of $\left.\mathrm{CH}_{2}\right), 4.88(\mathrm{dd}, 1 \mathrm{H}, J=8.7,3.4 \mathrm{~Hz}$ $\mathrm{CH}-\mathrm{OH}$ ), 7.24-7.28 (m, 2H, H3',5'-Ar), and 7.47-7.54 (m, 2H, H2', 6'-Ar).

\section{Results and discussion}

The aim of this research was to check the strains of $Y$. lipolytica with a known phenotype and genotype with respect to their ability to biotransform the prochiral mixed aliphatic-aromatic ketone acetophenone. The reduction ability of these strains was also evaluated. Because of the reversibility of the reduction observed in the latter experiment, biotransformations were also 
performed in a racemic mixture of 1-phenylethan-1-ol. Additionally, we studied enantioselective reduction of halogen derivatives of acetophenone in cultures of selected strains.

In order to check the influence of $S U C 2$ gene expression on the biotransformation process, experiments with biomass grown on MMT medium containing sucrose as the sole carbon source were also carried out.

Enantioselective reduction of acetophenone (1) in cultures of selected strains

The ability of the parental strain $Y$. lipolytica A-101 and its derivatives (A18, B54-6, B55-4, B57-4, A50, B9-2, B56-5, B14-6, Klon1) to reduce acetophenone (1) was assessed. The results showed that genetic modifications only slightly influenced the yield of the reduction and the enantiomeric excess of the obtained alcohol (2) (Table 1). An efficient reduction of the substrate took place in all of the cultures, leading to the anti-Prelog product $(R)$-1-phenylethan-1-ol (2) with high enantiomeric excess. Due to the reversibility of the acetophenone reduction reaction in the cultures of the selected strains (Fig. 1), the highest enantiomeric excess (ee $=80$ $90 \%$ ) for $(R)$-alcohol (2) was achieved as many as 9 days after the biotransformation (Table 1). After 1 day of substrate incubation, the $R$-alcohol was obtained with $50-60 \%$ of enantiomeric excess (data not shown). Our observations revealed that the longer the reaction time, the higher the predominance of this enantiomer, possibly explained by the oxidation of $S$-alcohol (2) back to the ketone (Figs. 1, 2). A similar tendency was observed for the $Y$. lipolytica strain ATCC 32-338A, where a gradual drop in $S$-alcohol content in relation to the $R$-alcohol (2) was noted. However, unlike the other tested strains, ATCC 32-338A produced predominantly (S)-1-phenylethan-1-ol (2), which is in accordance with the Prelog's rule (Fig. 2).

Biotransformations of racemic 1-phenylethan-1-ol (2)

The aim of the next experiment was to confirm that the reduction of acetophenone (1) is an equilibrium reaction. Therefore, a racemic mixture of 1-phenylethan-1-ol (2) was subjected to biotransformation. We observed a distinctive decrease in (S)-1-phenylethan-1-ol amount (2) and an increase in the $R$-enantiomer content of almost all tested strains after 6 (data not shown) and 9 days (Table 2) of the reaction. This result means that in the cultures of the tested strains the $S$ alcohol was oxidized to the ketone, and the formed acetophenone was reduced to $R$-alcohol $\mathbf{2}$. The highest biotransformation yields were observed for Y. lipolytica strain A101 with the suc ${ }^{-}$ura $^{-}$phenotype (A18 and B9-2). In the cultures of these strains $R$-alcohol 2 was obtained with the highest enantiomeric excess (Table 2; Fig. 3).
Table 1 Biotransformation of acetophenone (1) by selected Yarrowia lipolytica strains (after 9 days)

\begin{tabular}{lll}
\hline Strain & Conversion $(\%)^{\mathrm{a}}$ & ee of alcohol 2 (\%) \\
\hline Wild strains & \\
$\quad$ PMR-1 & $89(R)$ \\
A-101 & $91 \pm 2$ & $83(R)$ \\
Mutants & $93 \pm 0$ & \\
A-101-1.22 & & $80(R)$ \\
A-101-1.31-K1 & $82 \pm 2$ & $80(R)$ \\
A-101-1.31 & $85 \pm 4$ & $73(R)$ \\
ATTC 32-338A & $48 \pm 1$ & $36(S)$ \\
Clones & & \\
A18 & $89 \pm 3$ & $82(R)$ \\
B54-6 & $88 \pm 4$ & $88(R)$ \\
B55-3 & $94 \pm 2$ & $93(R)$ \\
Klon1 & $92 \pm 1$ & $89(R)$ \\
B1-1 & $92 \pm 4$ & $92(R)$ \\
A50 & $87 \pm 4$ & $88(R)$ \\
B56-5 & $94 \pm 1$ & $81(R)$ \\
B9-2 & $94 \pm 2$ & $90(R)$ \\
B14-6 & $92 \pm 1$ & $79(R)$ \\
B57-4 & $93 \pm 0$ & $83(R)$ \\
\hline
\end{tabular}

ee, Enantiomeric excess

${ }^{\text {a }}$ Values reported as the mean \pm standard deviation (SD)

On the basis of these results we selected the following strains for further experiments: parental strain Y. lipolytica A-101 and the strains B56-5 $\left(\mathrm{Suc}^{+} \mathrm{Ura}^{+}\right), \mathrm{A} 18\left(\mathrm{Suc}^{+} \mathrm{ura}^{-}\right)$ and $\mathrm{A} 50$ (suc $^{-}$ura $^{-}$).

Biotransformation of acetophenone by $\boldsymbol{Y}$. lipolytica A18 and B56-5 growing on sucrose

Due to the non-typical characteristic ability of Y. lipolytica to use sucrose as a carbon source, we cultivation all strains on a minimal growth medium MTM containing sucrose. The biotransformations were performed according to the procedure described in the section Screening procedure. The growth of the strain $Y$. lipolytica A18 was considerably inhibited (number of cells $3.2 \times 10^{7}$ cells $/ \mathrm{ml}$ ) and, therefore, the results of the reduction were poorer (enantiomeric excess up to $71 \%$, but the conversion was

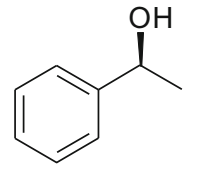

$(S)-2$

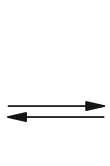

1<smiles>CC(=O)c1ccccc1</smiles>

(R)-2
Fig. 1 Reduction of acetophenone (1) to $(R)$-1-phenylethan-1-ol [(R)-2] and to $(S)$-1-phenylethan-1-ol $[(S)-2)]$ by Yarrowia lipolytica strains 

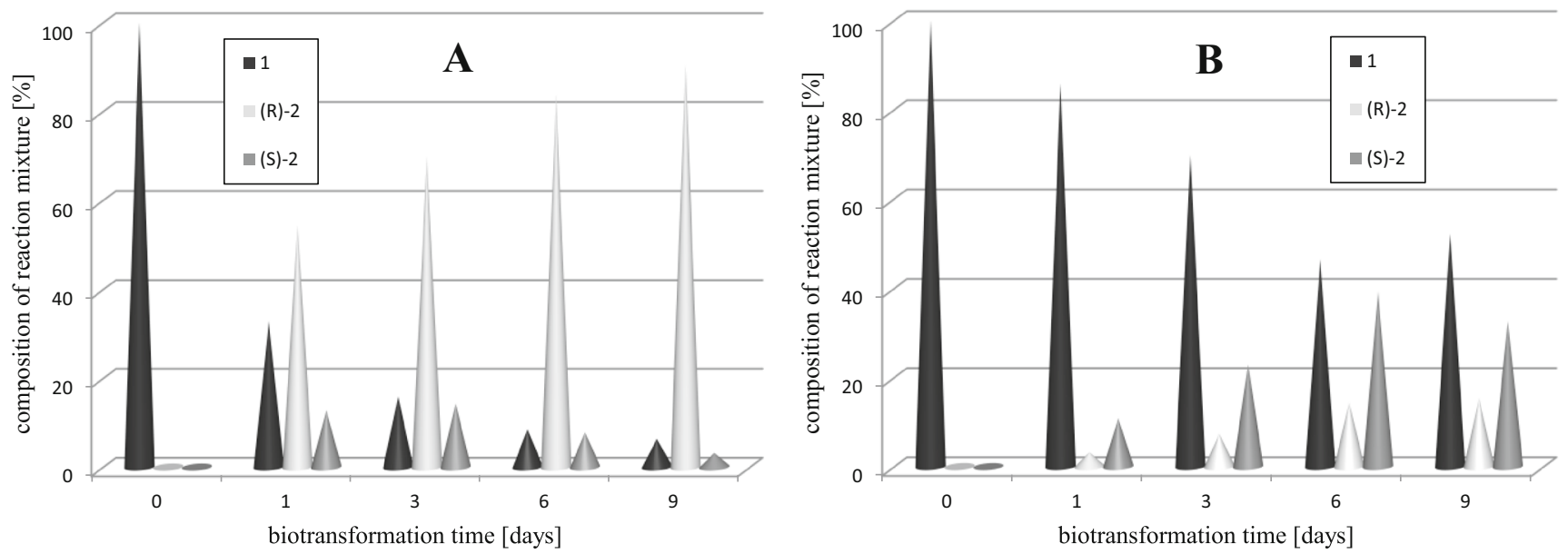

Fig. 2 Time-course of biotransformation of acetophenone (1) by Y. lipolytica B55-3 (a) and Y. lipolytica ATCC 32-338A (b)

only $23 \% 9$ days after the biotransformation). The strain Y. lipolytica B56-5 grew better and provided a much higher yield from the reduction (data not shown). The enantiomeric excess was comparable to the results obtained with yeast biomass growing on the rich culture media (YPG).

Biotransformation of halogen derivatives of acetophenone (1) by the parental strain

We next checked the ability of the strain Y. lipolytica A-101 to reduce five halogen derivatives of acetophenone (1): 2,4'dichloroacetophenone (3), 2,2',4'-trichloroacetophenone (4), 2-chloro-4'-fluoroacetophenone (5), 2-bromo-4'chloroacetophenone (6), and 2,4'-dibromoacetophenone (7) (Fig. 4).

Table 2 Biotransformations of 1-phenylethan-1-ol (2) by selected Y. lipolytica strains (results after 9 days).

\begin{tabular}{lll}
\hline Strain & $\begin{array}{l}\text { Percentage of alcohol } \\
\text { determined by GC }\end{array}$ & ee $(R)^{\mathrm{b}}$ \\
\hline A18 & $85 \pm 2$ & 49 \\
B54-6 & $85 \pm 3$ & 26 \\
B55-3 & $82 \pm 0$ & 51 \\
klon-1 & $71 \pm 5$ & 3 \\
B1-1 & $71 \pm 3$ & 25 \\
A50 & $80 \pm 1$ & 52 \\
B56-5 & $76 \pm 5$ & 15 \\
B9-2 & $82 \pm 1$ & 54 \\
B14-6 & $73 \pm 1$ & 36 \\
B57-4 & $83 \pm 2$ & 36 \\
A101 & $85 \pm 4$ & 19 \\
\hline
\end{tabular}

GC, Gas chromatography

${ }^{\text {a }}$ Values reported as the mean $\pm \mathrm{SD}$

${ }^{\mathrm{b}}$ Values reported as a percentage
It is worth noting that in the culture of Y. lipolytica A-101 the conversion was high (92-100 \%) for all of the substrates used in this experiment. As with acetophenone (1), the majority of the substrateswere reduced to the anti-Prelog alcohol. Only for the substrate with the third chlorine atom at C-2' (4) did we observe the opposite stereospecificity (Table 3 ). We also observed that the derivatives with bromine atom at $\mathrm{C}-2$ $(6,7)$ gave much lower enantiomeric excess (Fig. 4); for this group of substrates the reduction was reversible only for 2bromo-4'-chloroacetophenone (6) (Fig. 5).

Biotransformation of 2,4'-dichloroacetophenone (3) by selected strains derived from Y. lipolytica A-101

The tested strains of $Y$. lipolytica demonstrated different abilities to reduce 2,4'-dichloroacetophenone (3). Y. lipolytica B56-5 and A18, which possess the SUC2 gene, showed properties similar to the parental strain and reduced the substrate with an almost $100 \%$ yield and high (up to $70 \%$ obtained after 3 days of transformation) enantiomeric excesses

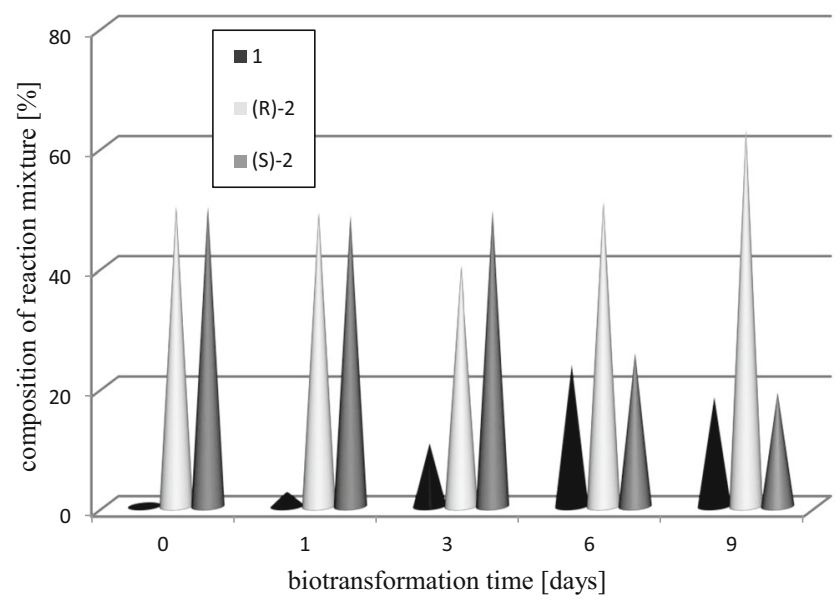

Fig. 3 Time-course of biotransformation of 1-phenylethan-1-ol (2) by Y. lipolytica $\mathrm{B} 9-2$ 
<smiles>[R]CC(=O)c1ccc([R])cc1[R]</smiles>

$\begin{array}{cccc}\text { compound } & { }^{1} \mathrm{R} & { }^{2} \mathrm{R} & { }^{3} \mathrm{R} \\ \mathbf{3 , 8} & \mathrm{Cl} & \mathrm{H} & \mathrm{Cl} \\ \mathbf{4 , 9} & \mathrm{Cl} & \mathrm{Cl} & \mathrm{Cl} \\ \mathbf{5 , 1 0} & \mathrm{F} & \mathrm{H} & \mathrm{Cl} \\ \mathbf{6 , 1 1} & \mathrm{Br} & \mathrm{H} & \mathrm{Cl} \\ \mathbf{7 , 1 2} & \mathrm{Br} & \mathrm{H} & \mathrm{Br}\end{array}$

Fig. 4 Halogen derivatives of acetophenone (1): 2,4'dichloroacetophenone (3), 2,2',4'-trichloroacetophenone (4), 2-chloro4'-fluoroacetophenone (5), 2-bromo-4'-chloroacetophenone (6) and 2,4'dibromoacetophenone (7). (2), (8-12) Racemic alcohols

of the resulting $S$-alcohol (8) (Table 3). The lowest both reduction yield (60-80\%) and enantiomeric excess (up to $33 \% 9$ days after biotransformation) were observed for Y. lipolytica A-101 A50 (data not shown). In this case, the strain ATCC 32-338A also performed the reduction with the opposite enantiospecificity, producing a poor yied of $R$-alcohol (8) (not exceeding $30 \%$ ) (Table 3).

Biotransformation of 2,2',4'-trichloroacetophenone (4) by the selected strain of $\boldsymbol{Y}$. lipolytica

The presence of the additional chlorine atom in the molecule of $2,2^{\prime}, 4^{\prime}$-trichloroacetophenone (4) explains why this compound is reduced to alcohol (9) with the opposite enantioselectivity, compared to the previous substrates. In this product, the $R$-enantiomer of alcohol (9) predominated. The results obtained are satisfactory; however, the conversion of the substrate is less efficient than that with the parental strain. For strain ATCC 32-338A, the conversion was much lower than that of the other tested strains, and the enantiomeric excess was also very low (the $S$ enantiomer predominated) (Table 3).

Biotransformation of 2-chloro-4'-fluoroacetophenone (5) by selected strains of $\boldsymbol{Y}$. lipolytica

Similarly to the parental strain Y. lipolytica A-101, the derived strains demonstrated a high capacity for biotransforming 2chloro-4'-fluoroacetophenone (5). The highest reduction yield, comparable to that of the parental strain, was observed for the clone with the $\mathrm{Suc}^{+} \mathrm{Ura}^{+} \mathrm{B} 56-5$ phenotype. Strains A18 and A50 showed a lower substrate conversion (71 and $55 \%$, respectively). The parental strain and all clones gave predominantly the $S$-enantiomer of alcohol (10). The highest enantiomeric excess was noted for the parental strain $(80 \%)$ and clone B56-5 (68\%). A relatively lower enantiomeric excess was observed for strains A18 (54\%) and A50 (48\%). The $R$ enantiomer of alcohol (10) was obtained in the culture of ATCC 32-338A, but at a low substarte conversion (12\%) (Table 3).

Biotransformation of 2-bromo-4'-chloroacetophenone (6) by selected strains of $\boldsymbol{Y}$. lipolytica

The reversible reduction processes were observed (similarly to the parental strain) in the case of the biotransformation of 2bromo-4'-chloroacetophenone (6) by the mutants of Y. lipolytica A-101. Due to changes in the composition of the reaction mixtures during incubation with the tested microorganisms, large differences among the results were noticed. The yields were high and the enantiomeric excesses were low. The parental strain produced $S$-alcohol (11) with an ee of $80 \%$, whereas strain A50, after a 1-day biotransformation, produced the $R$-enantiomer at an ee of $60 \%$. For the rest of the tested strains almost equimolar amounts of both enantiomers of (11) were obtained after 1 day of biotransformation. The most effective reduction of substrate (6) was achieved in the culture of strain ATCC 32-338A (Table 3).

Biotransformtion of 2,4'-dibromoacetophenone (7) by selected strains of $\boldsymbol{Y}$. lipolytica

Transformation of this substrate in the culture of strain ATCC 32-338A produced enantiopure $R$-alcohol (12) with a $100 \%$ conversion rate (after 3 days of biotransformation). Among the strains tested, the highest enantiomeric excess (22\%) of the $R$-alcohol was observed in the culture of strain $Y$. lipolytica A50, after 3 days of biotransformation (Table 3). The parental strain and the other clones reduced the substrate with a high degree of conversion, but with low enantiomeic excess.

The asymmetric reduction of ketones is one of the most important reactions leading to chiral alcohols, which serve as substrates in the production of many drugs, vitamins and chemicals used in modern agro-technology (Goswami et al. 2001; Yadav et al. 2001; Huang and Ying 2007). The results of our study indicate that the applied genetic modifications did not have a strong influence on reactivity compared to the parental strain. However, our results are a good starting point for strain selection and for further optimization of biotransformation conditions, with the aim of increasing yields and obtaining optically pure products.

In order to check the ability of the tested strains to perform a reduction, a prochiral mixed aliphatic-aromatic ketone, i.e. acetophenone (1), was used as a model substrate. All of the mutants tested were capable of the 
Table 3 Biotransformation of halogen derivatives of acetophenone (1) by selected strains of Y. lipolytica

\begin{tabular}{|c|c|c|c|c|c|}
\hline Strain & Substrate $^{\mathrm{a}}$ & Day & Conversion by GC $(\%)^{\mathrm{b}}$ & ee $(\%)$ & Configuration \\
\hline B56-5 & 3 & 1 & 100 & 63 & $S$ \\
\hline A18 & & 1 & 99 & 68 & $S$ \\
\hline \multirow[t]{2}{*}{ ATCC 32-338A } & & 1 & $20 \pm 3$ & 65 & $R$ \\
\hline & & 9 & $27 \pm 4$ & 67 & $R$ \\
\hline A50 & & 1 & $58 \pm 2$ & 31 & $S$ \\
\hline A-101 & & 1 & 100 & 86 & $S$ \\
\hline \multirow[t]{2}{*}{ B56-5 } & 4 & 1 & $89 \pm 1$ & 39 & $R$ \\
\hline & & 3 & 100 & 42 & $R$ \\
\hline \multirow[t]{2}{*}{ A18 } & & 1 & $58 \pm 2$ & 31 & $R$ \\
\hline & & 9 & $88 \pm 1$ & 47 & $R$ \\
\hline \multirow[t]{2}{*}{ ATCC 32-338A } & & 1 & $24 \pm 4$ & 2 & $S$ \\
\hline & & 3 & $62 \pm 1$ & 10 & $S$ \\
\hline \multirow[t]{2}{*}{ A50 } & & 1 & $57 \pm 2$ & 46 & $R$ \\
\hline & & 9 & 100 & 48 & $R$ \\
\hline A-101 & & 1 & 100 & 69 & $R$ \\
\hline B56-5 & 5 & 1 & $98 \pm 1$ & 68 & $S$ \\
\hline \multirow[t]{2}{*}{ A18 } & & 1 & $59 \pm 3$ & 54 & $S$ \\
\hline & & 9 & $71 \pm 3$ & 53 & $S$ \\
\hline \multirow[t]{2}{*}{ ATCC 32-338A } & & 1 & $11 \pm 1$ & 37 & $R$ \\
\hline & & 9 & $12 \pm 1$ & 48 & $R$ \\
\hline \multirow[t]{2}{*}{ A 50} & & 1 & $39 \pm 2$ & 48 & $S$ \\
\hline & & 9 & $55 \pm 1$ & 47 & $S$ \\
\hline A-101 & & 1 & $92 \pm 1$ & 80 & $S$ \\
\hline B56-5 & 6 & 1 & 100 & 12 & $S$ \\
\hline A18 & & 1 & 100 & 2 & $R$ \\
\hline ATCC 32-338A & & 1 & 100 & 74 & $S$ \\
\hline $\mathrm{A} 50$ & & 1 & 100 & 60 & $R$ \\
\hline \multirow[t]{2}{*}{ A-101 } & & 1 & 100 & 16 & $S$ \\
\hline & & 9 & 100 & 55 & $S$ \\
\hline B56-5 & 7 & 1 & 100 & 14 & $R$ \\
\hline A18 & & 1 & 100 & 9 & $R$ \\
\hline \multirow[t]{2}{*}{ ATCC $32-338 \mathrm{~A}$} & & 1 & $64 \pm 3$ & 100 & $R$ \\
\hline & & 3 & 100 & 100 & $R$ \\
\hline A50 & & 3 & 100 & 22 & $R$ \\
\hline A-101 & & 1 & 100 & 3 & $S$ \\
\hline
\end{tabular}

a (3), 2,4'-dichloroacetophenone; (4), $2,2^{\prime}, 4^{\prime}-$

trichloroacetophenone; (5), 2chloro-4'-fluoroacetophenone; (6), 2-bromo-4'-

chloroacetophenone; (7), 2,4'dibromoacetophenone

${ }^{\mathrm{b}}$ Values reported as the mean $\pm \mathrm{SD}$ and oxidation of xenobiotic substrates. Moreover, the clones of the Suc+ phenotype gained the ability to conduct biotransformations in growth media containing sucrose as a carbon source, which is not a typical characteristic of $Y$. lipolytica species.

Enantioselective reduction of acetophenone halogen derivatives was also performed. We observed that the nature and location of the halogen atom exerted a significant influence on the enantioselectivity of the reduction. A 3-day transformation of 2,4'-dibromoacetophenone (7) in the culture of ATCC 32338A strain resulted in the production of the enantiopure $R$ alcohol (12) at a substrate conversion rate of $100 \%$. Such a good result with respect to the enantiomeric excess was 


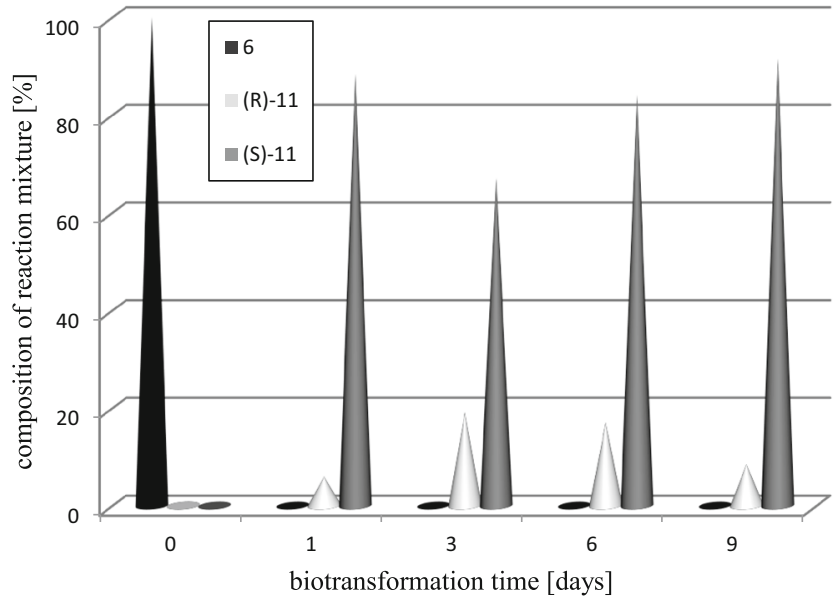

Fig. 5 Time-course of biotransformation of 2-bromo-4'chloroacetophenone (6) by Y. lipolytica A-101

unexpected because the other halogen derivatives were reduced by this strain much less effectively. This is a also notable result because this biotransformation gave no side products at all. In contrast, the production of additional side products have been observed in transformations of this substrate in cultures of other microorganisms (Rocha et al. 2010; Utsukihara et al. 2007).

Despite the fact that the strains of Y. lipolytica contain less selective alcohol dehydrogenases than some other biocatalysts catalyzing the enantioselective reduction of acetophenone and its halogen derivatives (Lin et al. 2009; Tokoshima et al. 2013), they do have a rare ability to reduce acetophenone to the anti-Prelog $R$-alcohol. However, the aim of our study, apart from presenting the capability of selected strains to perform the effective reduction, was to show differences in biocatalytic properties of strains within the same species. Moreover, we focused our attention to the reversibility of the reduction which takes place during biotransformation of the tested substrates in the cultures of Yarrowia lipolytica.

Open Access This article is distributed under the terms of the Creative Commons Attribution License which permits any use, distribution, and reproduction in any medium, provided the original author(s) and the source are credited.

\section{References}

Acker JI, Ozann C, Kachouri-Lafond R, Gaillardin C, Neuveglise C, Marck C (2008) Dicistronic tRNAe5S rRNA genes in Yarrowia lipolytica: an alternative TFIIIA-independent way for expression of 5S rRNA genes. Nucleic Acids Res 36:5832-5844

Alkasrawi M, Nandakumar R, Margesin R, Schinner F, Mattaisson B (1999) A microbial biosensor based on Yarrowia lipolytica for the off-line determination of middle-chain alkanes. Biosens Bioelectron 14:723-727
Bankar AV, Kumar AR, Zinjarde SS (2009) Environmental and industrial applications of Yarrowia lipolytica. Appl Microbiol Biotechnol 84: $847-865$

Basavaiah D, Reddy GJ, Chandrashekar V (2004) A new chiral catalytic source with an $\mathrm{N}-\mathrm{P}=\mathrm{O}$ structural framework containing a proximal hydroxyl group for the borane-mediated asymmetric reduction of prochiral ketones. Tetrahedron Asymmetry 15:47-52

Blazek J, Liu L, Redden H, Alper H (2011) Tuning gene expression in Yarrowia lipolytica by a hybrid promoter approach. Appl Environ Microbiol 77:7905-7914

Casaregola S, Neuveglise C, Lepingle A, Bon E, Feynerol C, Artiguenave F, Wincker P, Gaillardin C (2000) Genomic exploration of the hemiascomycetous yeasts: 17. Yarrowia lipolytica. FEBS Lett 487:95-100

Coelho MAZ, Amaral PFF, Belo I (2010) Yarrowia lipolytica: an industrial workhorse. In: Mendez-Vilas A (ed) Current research, echnology and education topics in applied microbiology and microbial biotechnology. Formatex Research Center, Badajoz, pp 930 944

Corey EJ, Helel CJ (1998) Reduction of carbonyl compounds with chiral oxazaborolidine catalysts: a new paradigm for enantioselective catalysis and a powerful new synthetic method. Angew Chem Int Ed 37:1986-2012

Czajgucka A, Chrzanowska J, Juszczyk P, Szołtysik M, Połomska X, Wojtatowicz M (2006) Wzrost drożdży w modelowym serze i ich wpływ na degradację białek i thuszczu. Acta Sci Pol Biotechnol 5: 95-103

Deak T, Chen J, Beuchat LR (2000) Molecular characterization of Yarrowia lipolytica and Candida zeylanoides isolated from poultry. Appl Environ Microbiol 66:4340-4344

Ding D-Q, Yamamoto A, Haraguchi T, Hiraoka Y (2004) Dynamics of homologous chromosome pairing during meiotic prophase in fission yeast. Dev Cell 6:329-341

Domínguez A, FermiNán E, Gaillardin C (2000) Yarrowia lipolytica: an organism amenable to genetic manipulation as a model for analyzing dimorphism in fungi. Contrib Microbiol 5:151-172

Fantin G, Fogagnolo M, Guerrini A, Medici A, Pedrini P, Fontana S (2001) Enantioselective hydrolyses with Yarrowia lipolytica: a versatile strain for esters, enol esters, epoxides, and lactones. Tetrahedron Asymmetry 12:2709-2713

Finogenova TV, Morgunov IG, Kamzolova SV, Chernyavskaya OG (2005) Organic Acid production by the yeast Yarrowia lipolytica: A review of prospects. Appl Biochem Microbiol 41:418-425

Förster A, Aurich A, Mauersberger S, Barth G (2007) Citric acid production from sucrose using a recombinant strain of the yeast Yarrowia lipolytica. Appl Microbiol Biotechnol 75: 1409-1417

Gasmi N, Fudalej F, Kallel H, Nicaud J-M (2001) A molecular approach to optimize hINF $\alpha 2 b$ expression and secretion in Yarrowia lipolytica. Appl Microbiol Biotechnol 89:109-119

Gasmi N, Ayed A, Nicaud J-M, Kallel H (2011) Design of an efficient medium for heterologous protein production in Yarrowia lipolytica: case of human interferon alpha 2b. Microbiol Cell Fact 10:38

Goswami J, Bezbaruah RL, Goswami A, Borthakur N (2001) A convenient stereoselective synthesis of $(R)-(-)$-denopamine and $(R)-(-)$ salmeterol. Tetrahedron Asymmetry 2:3343-3348

Hoff BH, Sundby E (2013) Preparation of pharmaceutical important fluorinated 1-arylethanols using isolated enzymes. Bioorg Chem $51: 31-47$

Huang X, Ying JY (2007) Asymmetric transfer hydrogenation over RuTsDPEN catalysts supported on siliceous mesocellular foam. Chem Commun 18:1825-1827

Janeczko T, Gładkowski W, Kostrzewa-Susłowa E (2013) Microbial production of dihydrochalcones and its derivatives as the food sweeteners. J Mol Catal B Enzym 98:55-61 
Juszczyk P, Musiał I, Rymowicz W (2005) Dobór szczepów drożdży do produkcji biomasy z glicerolu odpadowego. Acta Sci Pol Biotechnol 4:65-76

Knutsen AK, Robert V, Poot GA, Epping W, Figge M, Holst-Jensen A, Skaar I, Smith MT (2007) Polyphasic re-examination of Yarrowia lipolytica strains and the description of three novel Candida species: Candida oslonensis sp. nov., Candida alimentaria sp. nov. and Candida hollandica sp. nov. Int J Syst Evol Microbiol 57:2426-2435

Lanciotti R, Vannini L, Chaves Lopez C, Gobbetti M, Guerzoni ME (2005) Evaluation of the ability of Yarrowia lipolytica to impart strain-dependent characteristics to cheese when used as a ripening adjunct. Int J Dairy Technol 58:89-99

Lazar Z, Walczak E, Robak M (2011) Simultaneous production of citric acid and invertase by Yarrowia lipolytica $S U C^{+}$transformants. Bioresour Technol 102:6982-6989

Lazar Z, Rossignol T, Verbeke J, Crutz-Le Coq A-M, Nicaud J-M, Robak M (2013) Optimized invertase expression and secretion cassette for improving Yarrowia lipolytica growth on sucrose for applications. J Ind Microbiol Biotechnol 40:1273-1283

Li Y, Liu G-L, Wang K, Chi Z-M, Madzak C (2012) Overexpression of the endo-inulinase gene from Arthrobacter sp. S37 in Yarrowia lipolytica and characterization of the recombinant endo-inulinase. J Mol Catal B Enzym 74:109-115

Lin H, Chena Y-Z, Xua X-Y, Xia S-W, Wang L-X (2009) Preparation of key intermediates of adrenergic receptor agonists: Highly enantioselective production of $(R)$ - $\alpha$-halohydrins with Saccharomyces cerevisiae CGMCC 2.396. J Mol Catal B Enzym $57: 1-5$

Linder W, Rath M, Stoschitzky K, Semmelrock HJ (1989) Pharmacokinetic data of propranolol enantiomers in a comparative human study with (S)- and (R, S)-propranolol. Chirality 1:10-13

Madzak K, Gaillardin C, Beckerich J-M (2004) Heterologous protein expression and secretion in the non-conventional yeast Yarrowia lipolytica: a review. J Biotechnol 109:63-81

Mekour M, Blanc-Lenfle I, Ozanne C, Da Silva C, Cruad C, Wincker P et al (2010) Detection and analysis of alternative splicing in Yarrowia lipolytica reveal structure constrains facilitating nonsense-mediated decay of intron-retaining transcripts. Genome Biol 11:R65

Michely S, Gaillardin C, Nicaud J-M, Neuvéglise C (2013) Comparative Physiology of Oleaginous Species from the Yarrowia Clade. PLoS One 8:e63356

Mirończuk AM, Furgała J, Rakicka M, Rymowicz W (2014) Enhanced production of erythritol by Yarrowia lipolytica on glycerol in repeated batch cultures. J Ind Microbiol Biotechnol 41:57-64

Morgunov IG, Kamzolova SV, Perevoznikova O, Shishkanova NV, Finogenova TV (2004) Pyruvic acid production by thiamine auxotroph of Yarrowia lipolytica. Process Biochem 39: 1469-1477

Morgunov IG, Kamzolova SV, Lunina JN (2013) The citric acid production from raw glycerol by Yarrowia lipolytica yeast and its regulation. Appl Microbiol Biotechnol 97:7387-7397

Nakamura K, Yamanaka R, Matsuda T, Harada T (2003) Recent developments in asymmetric reduction of ketones with biocatalysts. Tetrahedron Asymmetry 14:2659-2681

Naumova ES, Serpova EV, Naumov GI (2010) Genome variability of the yeast Yarrowia lipolytica. Microbiology 79:229-236

Neuveglise C, Chalvet F, Wincker P, Gaillardin C, Casaregola S (2005) Mutator-like element in the yeast Yarrowia lipolytica displays multiple alternative splicings. Eukaryot Cell 4:615-624

Nicaud J-M (2012) Yarrowia lipolytica. Yeast 29:409-418

Nicaud J-M, Fabre E, Gaillardin C (1989) Expression of invertase activity in Yarrowia lipolytica and its use as a selective marker. Curr Genet $16: 253-260$
Nieduzak TR, Margolin AL (1991) Multigram lipase-catalyzed enantioselective acylation in the synthesis of the four stereoisomers of a new biologically actie $\alpha$-aryl-4-piperidinemethanol derivative. Tetrahedron Asymmetry 2:113-122

Omori ÁT, Assis LF, Andrade LH, Comasseto JV, Porto ALM (2007) Enantiomerically pure organoseleno-1-arylethanols by enzymatic resolution with Candida antarctica lipase: Novozym 435. Tetrahedron Asymmetry 18:1048-1053

Pagot Y, Le clainche A, Nicaud JM, Wache Y, Belin JM (1998) Peroxisomal $\beta$-oxidation activities and $\gamma$-decalactone production by the yeast Yarrowia lipolytica. Appl Microbiol Biotechnol 49: 295-300

Perez-Campo FM, Domínguez A (2001) Factors affecting the morphogenetic switch in Yarrowia lipolytica. Curr Microbiol 43:429-433

Ravindra AP (2000) Value-added food: single cell protein. Biotechnol Adv 18:459-479

Richard GF, Kerrest A, Lafontaine I, Dujon B (2005) Comparative genomics of hemiascomycete yeasts: genes involved in DNA replication, repair, and recombination. Mol Biol Evol 22:1011-1023

Robak M, Boruczkowski T, Drożdż W, Lazar Z, Baranowska M, Prządo D, Steininger M (2011) Zastosowanie drożdży Yarrowia lipolytica do bioremediacji gruntu zanieczyszczonego olejem kreozotowym. Ochrona Środowiska 33:27-33

Rocha LC, Ferreira HV, Pimenta EF, Souza Berlinck RG, Oliveira Rezende MO, Landgraf MD, Regali Seleghim MH, Sette LD, Meleiro Porto AL (2010) Biotransformation of $\alpha$ bromoacetophenones by the marine fungus Aspergillus sydowii. Mar Biotechnol 12:552-557

Rodríguez C, Borzęcka W, Sattler JH, Kroutil W, Lavandera I, Gotor V (2014) Steric vs. electronic effects in the Lactobacillus brevis ADH-catalyzed bioreduction of ketones. Org Biomol Chem 12:673-681

Rywinska A, Juszczyk P, Wojtatowicz M, Robak M, Lazar Z, Tomaszewska L, Rymowicz W (2013) Glycerol as a promising substrate for Yarrowia lipolytica biotechnological applications. Biomass Bioenergy 48:148-166

Sherman D, Durrens P, Beyne E, Nikolski M, Souciet J-L (2004) Génolevures: comparative genomics and molecular evolution of hemiascomycetous yeasts. Nucleic Acids Res 32:D315-D318

Thevenieau F, Nicaud J-M, Gailardin C (2009) Application of the nonconventional yeast Yarrowia lipolytica. In: Satyanarayana T, Kunze G (eds) Yeast biotechnology: diversity and applications. New Dehli, Springer Science, pp 589-613

Tokoshima D, Hanaya K, Shoji M, Sugai T (2013) Whole-cell yeastmediated preparation of (R)-2-chloro-1-(3-itrophenyl)ethanol as a synthetic precursor for (R)-phenylephrine. J Mol Catal B Enzym 97: 95-99

Tomaszewska L, Rymowicz W, Rywińska A (2014) Mineral supplementation increases erythrose reductase activity in erythritol biosynthesis from glycerol by Yarrowia lipolytica. Appl Biochem Biotechnol 172:3069-3078

Utsukihara T, Okada S, Kato N, Horiuchi CA (2007) Biotransformation of $\alpha$-bromo and $\alpha$-, $\alpha^{\prime}$-dibromo alkanone to $\alpha$-hydroxyketone and $\alpha$-diketone by Spirulina platensis. J Mol Catal B Enzym 45:68-72

Walczak E, Robak M (2009) Wzrost z sacharozy klonów drożdży Yarrowia lipolytica z genem inwertazy z Scharomyces cerevisiae. Acta Sci Pol Biotechnol 8:25-36

Wei Z-L, Li Z-Y, Lin G-Q (1998) anti-Prelog microbial reduction of Aryl $\alpha$-halomethyl or $\alpha$-hydroxymethyl ketones with Geotrichum sp. 38. Tetrahedron 54:13059-13072

White M, de Graaff P, Renshof B, van Kan E, Dzoljic M (2006) Pharmacokinetics of $\mathrm{S}(+)$ ketamine derived from target controlled infusion. Br J Anaesth 96:330-334 
Wojtatowicz M, Rymowicz W, Kautola H (1991) Comparison of different strains of the yeast Yarrowia lipolytica for citric acid production from glucose hydrol. Appl Biochem Biotechnol 31:165-174

Wojtatowicz M, Marchin GL, Erickson LE (1993) Attempts to improve the strain A-101 of Yarrowia lipolytica for citric acid production from n-paraffins. Process Biochem 28:453-460

Wojtatowicz M, Chrzanowska J, Juszczyk P, Skiba A, Gdula A (2001) Identification and biochemical characterization of yeast microflora of Rokpol cheese. Int J Food Microbiol 69:135-140

Xu G, Yu H, Xu J (2013) Facile access to chiral alcohols with pharmaceutical relevance using a ketoreductase newly mined from Pichia guilliermondii. Chin J Chem 31:349-354
Yadav JS, Thirupathy Reddy P, Nanda S, Bhaskar Rao A (2001) Stereoselective synthesis of $(R)-(-)$-denopamine, $(R)-(-)$ tembamine and $(R)-(-)$-aegeline via asymmetric reduction of azidoketones by Daucus carota in aqueous medium. Tetrahedron Asymmetry 12:3381-3385

Zhu D, Hyatt BA, Hua L (2009) Enzymatic hydrogen transfer reduction of $\alpha$-chloro aromatic ketones catalyzed by a hyperthermophilic alcohol dehydrogenase. J Mol Catal B Enzym $56: 272-276$

Żogała B, Mendecki MJ, Zuberek WM, Robak M (2012) Application of self potential method in the area contaminated with oil derivatives. Acta Geodyn Geomater 9:179-189 